Novák András:

\title{
MIGRÁCIÓ A BALKÁNON: HOGYAN LÁTJÁK A MENEKÜLTEK A BALKÁNI BEJUTÁST ÉS A SAJÁT HELYZETÜKET?
}

\author{
DOI: $10.35926 / \mathrm{HSZ} .2021 .6 .6$
}

ÖSSZEFOGLALÓ: Az elmúlt hat évben az illegális migráció első és talán legfontosabb útvonala a Balkánon át vezetett. 2015 és 2020 között a szerzőnek a munkája kapcsán rengeteg személyes találkozásban volt része, háromszáz menekültet pedig meg is interjúvolt utazásaik körülményeiről. Számos olyan kérdést tett fel, amelyek megválaszolásával talán közelebb juthatunk a migrációs válság megoldásához. Jelen dolgozatában röviden összefoglalja az újkori migráció kialakulását és a balkáni útvonal létrejöttét, ezután pedig ismerteti az általa készitett felmérés eredményét.

KULCSSZAVAK: migráció, ISIS, Balkán, menekültek, menekülttábor, embercsempészek

\section{A MIGRÁCIÓS VÁLSÁG KIVÁLTÓ OKAI}

Az ember bizonyos megközelítésben vándorló lény, ez viszont társadalmilag csak akkor elfogadható, ha nem veszélyezteti az egyes (kibocsátó, befogadó és tranzit-) országok, társadalmak normális létét, biztonságát. ${ }^{1}$

2015-ben rendkívüli migrációs válság alakult ki Európában, amely méretében, összetettségében és kiváltó okainak tekintetében is egyedülálló volt. Több mint 1,39 millió ember kért hivatalosan menedéket a kontinensen, sőt az Európai Határ- és Partvédelmi Ügynökség - közismertebb nevén Frontex - számításai szerint akár a kétmilliót is elérhette az Európába érkezett menekültek száma. Nem véletlenül nevezi a szakirodalom és a politikai közbeszéd is a jelenséget a második világháború óta tapasztalt legsúlyosabb menekültválságnak a kontinensen. Legtöbben az Iszlám Állam terrorszervezet létrejöttét, tagjai és támogatói által a lakosság ellen elkövetett brutális terrorcselekményeket tartják a drasztikus menekülthullám megindulása fő okának.

A terrorizmus mint globális jelenség magában hordozza a hálózatrendszerek kiépülését. A folyamat eredményeként számos, korábban jobbára elszigetelt közösség válik a nemzetközi terror részesévé. ${ }^{2}$

A szunnita szélsőséges csoportoknak - amelyek a politikai rendszer megváltoztatásáért harcolnak és általános jogokat követelnek - jó lehetőségeket biztosított a terjeszkedésre az instabil iraki belpolitikai helyzet, valamint az évek óta tartó szíriai polgárháború. A 2014-ben megalakított Iszlám Állam (Iraki és Levantei Iszlám Állam, Iraki és Szíriai Iszlám Állam,

\footnotetext{
Andorka Rudolf: Bevezetés a szociológiába. Osiris, Budapest, 2006, 162-175.

2 Kasznár Attila: Az ujgur terrorizmus nemzetközi biztonsági kockázatai. Arc és Álarc, I. évf. 2017/2-3., 181-189.
} 
angol rövidítéssel és a továbbiakban: ISIS) is ilyen volt, s mint terrorszervezet, rendkívül sikeresnek számított: jól szervezett, jól finanszírozott volt, és az egyik legveszélyesebb nemzetközi csoportként tartották számon. Kialakult tehát ez a nemzetállami jellemzőket is magán viselö, szervezett terrorista egység, amely a bizonytalan helyzetben tömegeket állított maga mellé azzal, hogy védelmet és szociális ellátóhálózatokat épített ki. A szabad nemzetek általános felfogása szerint ez egy gyilkos, diktatórikus képződmény, a belülről fakadó hatalmas támogatottság miatt mégis önállóságra tett szert, s hosszú ideig életképes maradt.

Az ISIS eredeti célja egy kalifátus létrehozása volt, amely magában foglalja többek között Szíria és Irak szunnita többségű területeit, illetve a közel-keleti régió jelentős részét (beleértve Jordániát, Izraelt, Palesztinát, Libanont, Ciprust és Törökország déli részét). Az ISIS által időszakosan létrehozott kalifátust egyetlen ország vagy nemzetközi szervezet sem ismerte el hivatalosan létező, önálló államnak. Kétségbevonhatatlan ugyanakkor, hogy de facto létező területtel, lakossággal rendelkezö és állami funkciókat is ellátó vallási-társadalmi képződményről beszélünk. Amennyiben azonban figyelembe vesszük az alapvető céljait, módszereit, tevékenységét és a nemzetközi kapcsolatokhoz való viszonyulását, akkor csak terrorista szervezetnek minősíthetjük. Katonai szempontból az ISIS alapvetően egy mozgékony, a szárazföldi csapatok tulajdonságaival rendelkező szervezett erőnek volt tekinthető. Az ISIS többféle harctevékenységi formát kombinált az öngyilkos merényletektől az aszimmetrikus hadviselési jellemzőket mutató hagyományos szárazföldi harcig (lakott települések megerösítése, az ott folytatott müveletek védelme stb.).

Számos tényező járult hozzá az ISIS térnyeréséhez és terjeszkedéséhez. Az iraki és szíriai válság helytelen kezelése, valamint a radikális militáns iszlám és a növekvő dzsihádizmus mind növelhették eredményességét. ${ }^{3}$ Az Iszlám Állam térhódítását az iraki alkotmány azon rendelkezése is segítette, hogy egy törvény sem állhat összeütközésben az iszlámmal. A valóságban ez azt jelenti, hogy a kisebbségek nem gyakorolhatják a vallásukat, s törvény tiltja a muszlimok más hitre való áttérését. Az egyik legjelentősebb tényező azonban az volt, hogy az ISIS az iraki konfliktus és a szíriai polgárháború okozta politikai űrt sikeresen használta ki, és 2014-ben Szíria és Irak jelentős területeit rövid idő alatt el tudta foglalni. Ehhez az is hozzájárult, hogy az iraki rendvédelmi erők gyakorlatilag semmilyen ellenállást nem tanúsítottak a szervezettel szemben. A szervezeti fegyelem és az elfoglalt területeken az állami szolgáltatások azonnali megszervezése nagymértékben segítette a kalifátus létrehozását, amelyet 2014. június 29-én kiáltott ki a szervezet vezetője Moszulban. ${ }^{4}$

Kiemelendő, hogy az ISIS képes volt kulcsfontosságú természeti erőforrásokat elfoglalni Szíria és Irak területén, amelyek révén saját müködését finanszírozta. Ezenfelül a terrorszervezet az elfoglalt területeken saját központi bankot hozott létre, valamint saját arany-, ezüst- és rézpénzt adott ki.

Az ISIS gyors térnyerésének, sikerének egyik meghatározó oka a közösségi médiában folytatott tudatos programja volt. Ennek a kampánynak a legfőbb célja a toborzásban, valamint adományok, anyagi segélyek megszerzésében és begyűjtésében, illetve a folyamatos fenyegetés fenntartásában merült ki. Az ISIS rendkívül gyors sikere mindezen tényezők párhuzamos bekövetkeztének eredménye. ${ }^{5}$

\footnotetext{
Szilágyi-Kiss Hajnalka: Az Iszlám Állam megerősödésének logisztikai háttere. Honvédségi Szemle, 149. évf. 2021/5.

4 Háber Péter: Az „Iszlám Állam” nevű terrorista szervezet és az általa gerjesztett biztonsági kockázatok. Szakmai Szemle, 2016/3., 55-82.

5 Resperger István (szerk.): Nemzetbiztonsági alapismeretek. Dialóg Campus Kiadó, Budapest, 2018, 72-75.
} 
A migrációt kiváltó és felerősítő tényezőkre a legjobb példák a szíriai, az iraki, az afgán és a líbiai konfliktusok. Ezek azok az évek óta elhúzódó események, amelyeknek a statisztikai adatok alapján meghatározó szerepük volt a 2015-ös európai migrációs válság kialakulásában. Míg 2015-ben az Európába érkező migránsok között a szíriai, az iraki és az afgán polgárháború elől menekülők voltak a legnagyobb arányban (szíriai 29\%, afgán 19\%, iraki 13\%), ${ }^{6}$ addig a Kadhafi-rendszer összeomlása és az azt követő líbiai káosz a szubszaharai térség fegyveres konfliktusai (Nigéria, Eritrea és Szomália) elől menekülők számára nyitotta meg a kaput Európa felé. 2011 előtt ugyanis az észak-afrikai autoriter rendszereknek kulcsszerepük volt az Afrikából érkező migránsok feltartóztatásában, azonban a jelenlegi Líbia képtelen ezt a feladatot ellátni. Az ISIS 2014-es katonai megerősödésével és terjeszkedésével, illetve az ellene való nemzetközi fellépéssel azonban - vagyis a 2014 szeptemberében meginduló és 2017-ig elhúzódó bombázásokkal - ez a helyzet alapvetően megváltozott. Az életkörülmények az ISIS által elfoglalt vagy a más felkelők által uralt területeken drasztikusan romlottak. A regnáló kormány Szíriában egyre kevésbé volt képes ellátni az általa ellenőrzött területek lakosságát, amelynek létszáma a belső menekültek megjelenésével 2015 közepére gyakorlatilag megduplázódott. Mindezek következtében valószínüleg még azok is elbizonytalanodtak (s a migráció mellett döntöttek), akik reménykedtek abban, hogy a szíriai kormánycsapatok rövid idő alatt visszaállítják a rendet az országban.

A Közel-Kelet politikai helyzete ingatag, és az elmúlt fél évszázadban több ízben helyi fegyveres konfliktusok színterévé vált. Ez is közrejátszott abban, hogy az emberek időről időre útnak indultak ebből a térségből. ${ }^{7}$ A fegyveres konfliktusokon túl, a szociális-egészségügyi helyzet, az ivóvízhiány okozta gondok és a rossz élelmezési lehetőségek is hozzájárulnak a menekültáradat megindulásához. ${ }^{8}$

Az iszlám tanulmányokat is folytató, közel húsz éve a térségben élö német KözelKelet-szakértő, Rainer Hermann szerint „,[d]öntő jelentősége lesz annak, hogy sikerül-e megakadályozni az eszkaláció negyedik szintjét, hogy sikerül-e csökkenteni a feszültséget. A Nyugat ebben a háborúban csak járulékos segítséget nyújthat a mérsékelt muszlimoknak". 9

Az arab tavasz egyik hatásaként jelentős menekülthullám indult meg az észak-afrikai és a közel-keleti régióban, ami Európát is érinti. ${ }^{10}$ Habár a 2014-ben kezdődött menekülthullám napjainkra csökkent, azonban változatlanul az egyik legfontosabb problémát jelenti Európa államainak.

A ,menekült” pontos definícióját a menekültek jogállásáról szóló 1951-es egyezményben, az ún. genfi konvencióban fektették le. Ennek értelmében a menekült olyan személy, aki „faji, vallási okok, nemzeti hovatartozása, illetve meghatározott társadalmi csoporthoz való tartozása, avagy politikai meggyőződése miatti üldözéstől való megalapozott félelme miatt az állampolgársága szerinti országon kívül tartózkodik, és nem tudja, vagy az üldözéstől való félelmében nem kívánja annak az országnak a védelmét igénybe venni; vagy

6 Tálas Péter: Az európai migrációs válság értelmezési kereteiről. Nemzet és Biztonság, 2016/6., 86-115.

${ }^{7}$ Dr. Probáld Ferenc - Dr. Szegedi Nándor: Afrika és a Közel-Kelet gazdaságföldrajza. Tankönyvkiadó Vállalat, Budapest, 1986, 34-35.

${ }^{8}$ Dr. Dezső Tamás: Demográfia és migráció: a muszlim világ népességrobbanásának okai és következményei. Migrációkutató Intézet. https:/www.migraciokutato.hu/2018/12/11/a-muszlim-vilag-nepessegrobbanasanakokai-es-kovetkezmenyei/ (Letöltés időpontja: 2019. 12. 09.)

9 Rainer Hermann: Az Iszlám Állam. A világi állam kudarca az arab világban. Akadémiai Kiadó, Budapest, 2015, 59.

10 Simon Péter: Az arab tavasz kiváltó okai, jelene és hatása a biztonságpolitika alakulására. Felderítő Szemle, XIII. évf. 2014/1., 17-25. 
aki állampolgársággal nem rendelkezve és korábbi szokásos tartózkodási helyén kívül tartózkodva ilyen események következtében nem tud, vagy az üldözéstől való félelmében nem akar oda visszatérni”. ${ }^{11}$

Az arab tavaszt követően egy le nem zárult polgárháború zajlik. A menekülni kényszerülő szíriaiak egy része hazájának polgárháború által nem sújtott részeibe menekült, egy másik hányada - illetve az előbbiekből időközben azok is, akiket a polgárháború terjedése „kiszorított” az országból - kénytelen volt elhagyni hazáját; ez 2015 közepén 4,2 millió föt jelentett. ${ }^{12}$ Az ISIS elől szinte felekezeti különbség nélkül mindenki, még a szunniták is menekülnek. Az elmúlt öt év alatt 234 ezer szír állampolgár folyamodott menedékért az EU országainak valamelyikében. Eközben csak Törökországban 1,5 millió szír menekült tartózkodik, vagyis a szír menekültproblémának mindössze egy töredéke jelentkezik Európában.

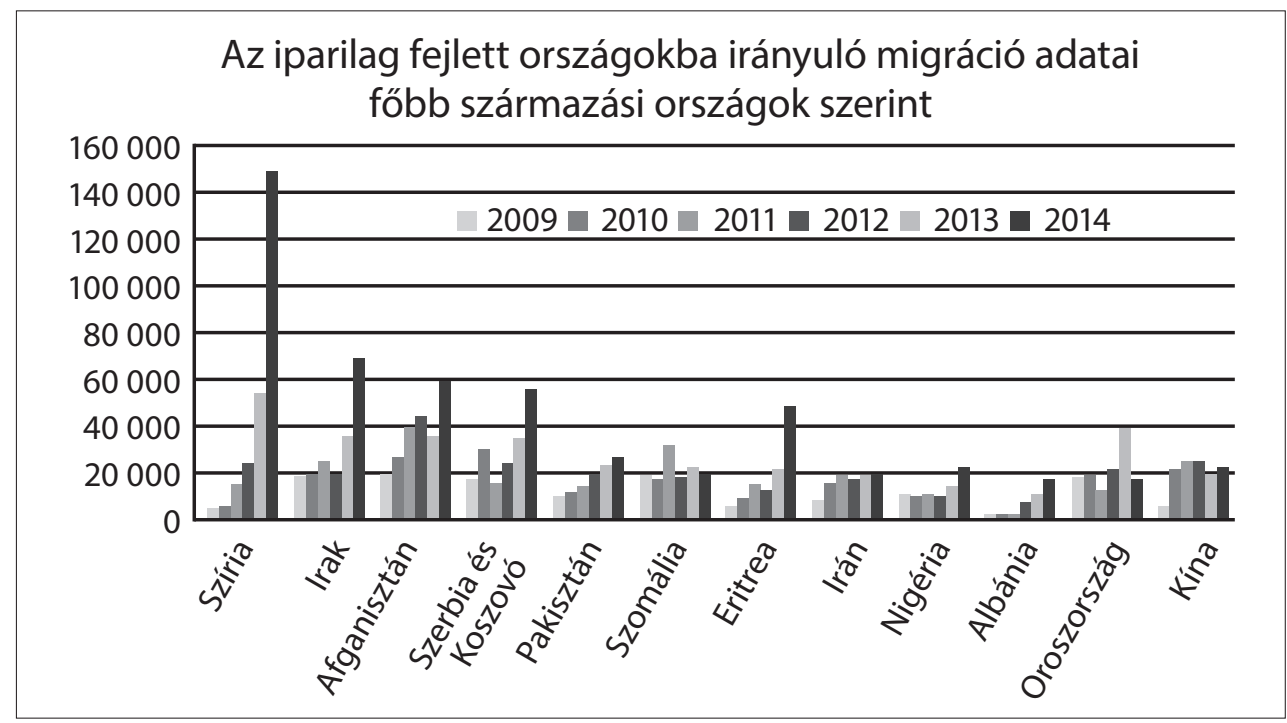

1. ábra Az iparilag fejlett országokba irányuló migráció adatai föbb származási országok szerint (Forrás: Ritecz György: A migráció trendjei - és ami mögötte van. Regio, 24. évf. 2016/2., 117. [Letöltés idöpontja: 2019. 09. 10.])

Az Európába tartó menekülők zöme (38,6\%) egy szük régióból (Irak, Afganisztán, Pakisztán, Irán, Szíria) érkezik. Vagyis azokból az országokból, amelyekben a Nyugat vívott háborút - elvileg - humanitárius célból, majd csapataik nemrég kivonultak onnan, lényegében káoszt hagyva maguk után, ami befejezetlen konfliktuskezelést, politikailag és gazdaságilag is rendezetlen viszonyokat jelent. ${ }^{13}$

Az állam intézménye nem mủködik sem Irakban, sem Afganisztánban, így nem csoda, hogy aki teheti, eljön onnan. A másik ilyen terület a Szubszahara térsége (Fekete-Afrika) és

11 1989. évi 15. törvényerejü rendelet a menekültek helyzetére vonatkozó 1951. évi július hó 28. napján elfogadott egyezmény, valamint a menekültek helyzetére vonatkozóan az 1967. évi január hó 31. napján létrejött jegyzőkönyv kihirdetéséről. 1. cikk (2). https://net.jogtar.hu/jogszabaly?docid=98900015.tvr (Letöltés idôpontja: 2020. 04. 12.)

12 unher.org.hu

${ }^{13}$ Ritecz György: A migráció trendjei - és ami mögötte van. Regio, 24. évf. 2016/2., 109-139. DOI: http://regio. tk.mta.hu/index.php/regio/article/view/115 (Letöltés időpontja: 2019. 09. 10.) 
„Afrika szarva” (Északkelet-Afrika), amely régiók országaiban már több éve polgárháború zajlik, és a Nyugat semmit sem volt képes tenni a polgári lakosság védelme érdekében.

A globális statisztikában is érzékelhetővé vált egy kvázi egyedi eset: a Szerbiából és a statisztikailag még hozzá tartozó Koszovóból menekülők ügye. A Nyugat-Balkánon az ottani megoldatlan konfliktusok a múltban már nemegyszer olyan háborúkhoz vezettek, amelyeket az egész világ megszenvedett. Ezek a kiváltó okok továbbra is fennállnak, és a húsz évvel ezelőtti balkáni rendezés sem oldotta meg, csak elodázta kezelésüket. ${ }^{14}$ 2009-ben még kevesebb mint 17 ezer (16 981) fő indult el Koszovóból az Európai Unió felé, 2013-ban ennek a duplája (34 347 fö), majd 2014-ben ismét majdnem megduplázódott a számuk (55 668 fő). Ennek következtében a legfejlettebb 44 országba benyújtott menekültkérelmek alapján a negyedik legjelentősebb származási országnak Koszovó tekinthető. ${ }^{15}$ Koszovó nagyon jó táptalajt nyújt a szervezett bünözői csoportoknak, amelyek a „,magyarországi joghézagot” felismerve tudatos kommunikációval és jól szervezett módon tömegeket csempésztek az EU területére. Természetesen mindezzel dollár- vagy eurómilliókat keresve.

Fontos megjegyezni, hogy a balkáni régió államai tranzitországnak számítanak, tehát az ide érkezők nem itt szeretnének munkát vállalni vagy a menedékkérelmüket benyújtani. ${ }^{16}$

\section{Főbb Frontex-adatok}

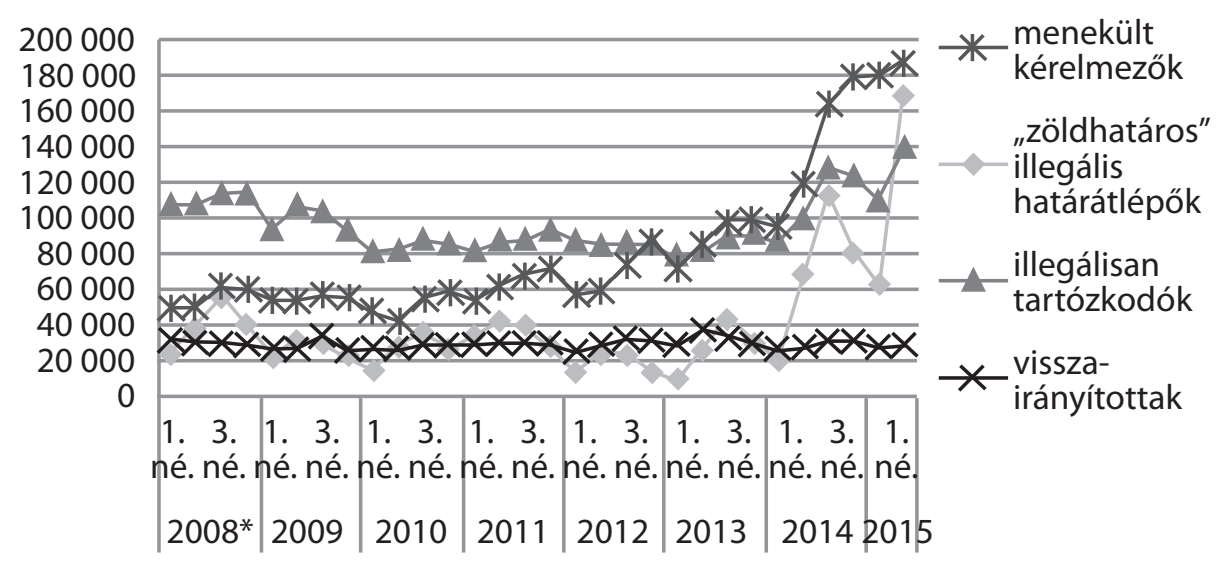

2. ábra Főbb Frontex-adatok (Forrás: Ritecz: i. m. 127.)

Az ún. kilencek (Cseh Köztársaság, Észtország, Lengyelország, Lettország, Litvánia, Magyarország, Málta, Szlovákia és Szlovénia) schengeni övezethez való csatlakozása óta

\footnotetext{
${ }^{14}$ Magyar Levente: A migráció a legnagyobb biztonsági kihívás Európában. https://magyarnemzet.hu/kulfold/magyarlevente-a-migracio-a-legnagyobb-biztonsagi-kihivas-europaban-7563518/(Letöltés időpontja: 2019. 12. 06.)

${ }^{15}$ Huszonkét éve nem látott számú menedékkérő érkezett 2014-ben a világ fejlett ipari országaiba. https://www. unhcr.org/hu/393-huhirek2015huszonket-eve-nem-latott-szamu-menedekkero-erkezett-2014-ben-a-vilag-fejlettipari-orszagaiba-html.html_(Letöltés időpontja: 2019. 11. 03.)

16 Besenyő János - Miletics Péter József (szerk.): Szemelvények a XXI. századi migráció témaköréből. Honvéd Vezérkar Tudományos Kutatóhely (HVK TKH), Budapest, 2017. http://real.mtak.hu/83709/1/szemelvenyek.pdf (Letöltés időpontja: 2020. 03. 22.)
} 
a visszairányítottak (refusals of entry) száma lényegében stagnál, vagyis a határátkelöhelyeken a kockázatot jelentő személyek száma nem csökkent, de nem is nőtt az elmúlt hét évben. Az illegálisan tartózkodók (illegal stay) száma 80-100 ezer (felfedett) személyt jelentett negyedévente. 2017-ben emelkedett a 2008-as szintre, illetve minimálisan a fölé. Tehát hosszabb távon nem érzékelhető migrációs nyomás a határátkelöhelyeken. Az ún. zöldhatáros (határátkelőhelyek közötti, ideértve a tengereken átjutni akarókat is) illegális határátlépők (illegal bordercrossing between BCPS) száma is egyfajta enyhén csökkenő tendenciát mutatott 2008-2013 között (40-20 ezer/negyedéves nagyságrenddel), de 2014 III. negyedévére megugrott a 110 ezres nagyságrend fölé, majd a következő két negyedévben már lecsökkent a 80 ezres, illetve a 62 ezres szintre. 2015 II. negyedévében a zöldhatáros illegális határátlépők száma 170 ezer főre emelkedett. Ezzel szemben a menekültkérelmet benyújtók száma (a Frontex adatai szerint) 2008-2011 között negyedévente stabilan 50-60 ezer föt mutatott, majd dinamikus emelkedésbe kezdett, míg végül 2014-ben kiugró (2014. IV. negyedévben 180715 fó) adatot produkált, amelyet 2015 I. és II. negyedévében megismételt (181569 és 187437 fö $\left.^{17}\right){ }^{18}$

2014-ben viszont történt valami. Tudjuk, hogy korábban negyedévente 5-20 ezer föt fogtak el (külön-külön) a tengeri (sea border) és a szárazföldi (land border) zöldhatáron. 2014 II. negyedévében viszont már a tengeren 61 ezernél is több migránst tartóztattak fel a határrendészek, a III. negyedévben pedig már közel 100 ezret (97 936 fó), majd a IV. negyedévben további 46 ezer migránst, de 2015 I. negyedévében már ismét „csak” 23 ezer föt fedtek fel az európai ún. kékhatárokon. 2015 tavasza viszont új csúcsot eredményezett: negyedév alatt 127 ezer föt. ${ }^{19}$ Eközben a szárazföldön 2014-ben (a tengerihez képest) enyhe emelkedés mutatható ki. A 2014. I. negyedévi 7 ezerról fokozatosan 34 ezerre emelkedett az elfogottak száma, ami 2015-ben tovább emelkedett 42 ezer főre.

A 2014-es tengeri elfogások döntő többsége az olasz tengeri térségben történt. Elöször is az arab tavaszt követően, az időszakos konszolidáció után Tunéziában egyfajta anarchikus állapot alakult ki, ahol a szervezett bünözői bandák szabadon garázdálkodtak. Ugyanez volt a helyzet Líbiában, annyi különbséggel, hogy itt még konszolidáció sem volt, és szinte (törzsi) polgárháború dúlt (ez az ún. push factor). Vagyis a szervezett bünözök zavartalanul üzhették a nagy haszonnal kecsegtető csempészetet, akik, mint tudjuk, az emberek mellett az ország olajkészleteinek jó részét is kicsempészik az országból.

2013 októberében Lampedusa közelében több mint háromszáz migráns vesztette életét. Erre az Európai Tanács döntésének megfelelően, a Frontex koordinálásával és az EU finanszírozásával - alapvetően az olasz hatóságok által, bevonva a haditengerészetet is - megkezdődött az ún. Mare Nostrum-akció. Ennek lényege, hogy nem az olasz partok elött, hanem az afrikai partokhoz közel (de még nemzetközi vizeken - a nemzetközi jogi bonyodalmak elkerülése végett) járöröztek a továbbiakban, hogy lehetőleg minél kevesebben jussanak ki a nyílt nemzetközi vizekre, és ha lehet, többen már ne fulladjanak bele a tengerbe menekülés közben. Vagyis lényegében a csempészett személyek elé mentek (ez a pull factor), és már nem kellett közel öt napot hánykolódni a tengeren, mire eljutottak az olasz felségterületre, hanem alig ötórás út után felvették őket az olaszok (később más EU-államok is) hajói és beszállították

\footnotetext{
17 Ritecz György - Sallai János: A migráció trendjei, okai és kezelésének lehetőségei 2.0. Central European Papers, IV. évf. 2016/2., 104-106.

$18 \mathrm{http}: / /$ www.bmbah.hu/index.php?option=com_k2\&view=itemlist\&task=category\&id=11:bekescsaba\&Itemid=8 85\&lang=hu (Letöltés időpontja: 2019. 01. 13.)

19 http://bamf.de/EN/DasBAMF/dasbamf.node.html (Letöltés időpontja: 2019. 09. 10.)
} 
őket az olasz (schengeni) területre. Ezt felismerve, a csempészek egyre több kisebb és/vagy rosszabb állapotú hajóba zsúfoltak rengeteg embert, megígérve nekik, hogy elérik a „közeli” EU-s hajókat. Lényegében tehát az olasz hatóságok (az EU jóváhagyásával) gerjesztették ezt a migrációs hullámot. Jól mutatja ezt, hogy 2014 III. negyedévében a 97 ezer tengeren átkelö menekült harmada (33 381 fö) szír állampolgár volt. Földrajzilag Európa irányába nem ez volt a leglogikusabb útvonal a számukra, de gyakorlatilag ez volt a leggyorsabb és „legbiztonságosabb”. Érzékelve a húzóeffektus nem kívánt hatását, a nemzetközi akciót 2014 szeptembere és decembere között fokozatosan leállították. Ennek következménye az lett, hogy az utolsó negyedévben az előző felére, majd 2015 elején tovább csökkent az elfogások (tengeri kimentések) száma. Eközben a szárazföldi elfogások száma éppen az említett két utolsó negyedévben emelkedett, vagyis tipikus „terelöhatás” lépett életbe. Ha az átjutás nem sikerül, illetve nehezen megy az egyik szakaszon (migrációs útvonalon), akkor a másikra terelődik a migrációs nyomás.

2015-ben a jó idő beálltával ismét próbálkoztak a csempészek, és újabb hajókat indítottak, de ekkor már nem voltak ott az afrikai partok közelében „az EU hajói”, így be is következett a tragédia: újabb 900 ember fulladt egyszerre a Földközi-tengerbe. Ugyanis az ISIS terjeszkedése és tevékenysége egyre intenzívebbé vált, az ENSZ Menekültügyi Főbiztosának (UN Refugee Agency, UNHCR) menekültügyi ellátásra fordítható pénze is egyre csökkent. A közel-keleti, de föleg a törökországi menekülttáborokban az állapotok (azaz az életminőség) egyre kritikusabbá váltak, így mind nagyobb tömegek indultak útnak. Egyes afgán csoportok azért menekültek, mert attól féltek, hogy hazájukban is tért hódít az ISIS. Mások, akik mindaddig abban reménykedtek, hogy előbb-utóbb véget ér a polgárháború hazájukban és hazatérhetnek, reményt vesztve arra kényszerültek, hogy otthagyják az ,időszakos" sátortáborokat, és maguknak, illetve a családjuknak (gyermekeiknek) jobb életet, jövőt remélve egy biztonságosnak tekinthető, „normális” államban keressenek új hazát. ${ }^{20}$ Ebben közrejátszhatott az is, hogy 2014-ben és 2015 első felében a schengeni térségbe már bejutottak - a modern kommunikáció segítségével - nemcsak arról számolhattak be az otthon maradóknak, hogy kijutottak és az életkörülményeik egészen kedvezők, hanem az útvonalról, csomópontokról, kontaktszemélyekről is szinte folyamatos tájékoztatást adva, lényegében digitálisan irányítva segítették a következő (egyre nagyobb) hullámot. ${ }^{21}$

\section{KUTATÁS A MIGRÁNSOKKAL KÉSZÜLT INTERJÚKBÓL}

A következő felmérés nem reprezentatív, mégis igen egységes képet mutat a különböző országokból érkezők hátteréről, indokairól és illegális határátlépéseiről. A kérdéseket - miután televíziós riporter vagyok - úgy állítottam össze, hogy azokra a témákra adjanak választ, amelyek a legjobban érdekelhetik az embereket és a szakértőket.

Kutatómunkámat 2013 és 2020 között végeztem tizenkét országban (Szíria, Kurdisztán, Irak, Törökország, Észak-Macedónia, Görögország, Szerbia, Bosznia, Horvátország, Olaszország, Líbia, Libanon). Úgy vélem, ezeket az információkat szinte a teljes érkező tömegre rá lehet vetíteni. A kutatás eredetileg televíziós interjúgyüjteménynek készült, így továbbfejlesztve és részletesebben kidolgozva a témát egy kifejezetten érdekes és komoly tanulságokat lehet belöle levonni.

\footnotetext{
${ }^{20}$ Csuka Gyöngyi - Török Ádám (szerk.): Az Európába irányuló és 2015-től felgyorsult migráció tényezői, irányai és kilátásai. MTA Migrációs Munkacsoport, Budapest, 2015.

${ }^{21} \mathrm{https} / /$ frontex.europa.eu/search-results/?q=In+2014+and+the+first + half + of $+2015+$ to + the + Schengen + area (Letöltés időpontja: 2019. 02. 11.)
} 
A kérdéssorban közel háromszáz menekült válaszait összesítettem. Ezeknek a kamerával készített interjúknak a nagy része már adásba került. Egy-egy interjúrészletet külön is leírok, hogy így tudjam érzékletesebben ismertetni az érkezők véleményét és a tőlük kapott információt.

Az érkezőket három csoportba soroltam az indulási régió szerint: Közel-Kelet, Ázsia és Afrika. A felmérésemben abban az esetben választottam szét a más területről érkezők válaszait, ha az átlaghoz képest feltünően eltérő választ adtak.

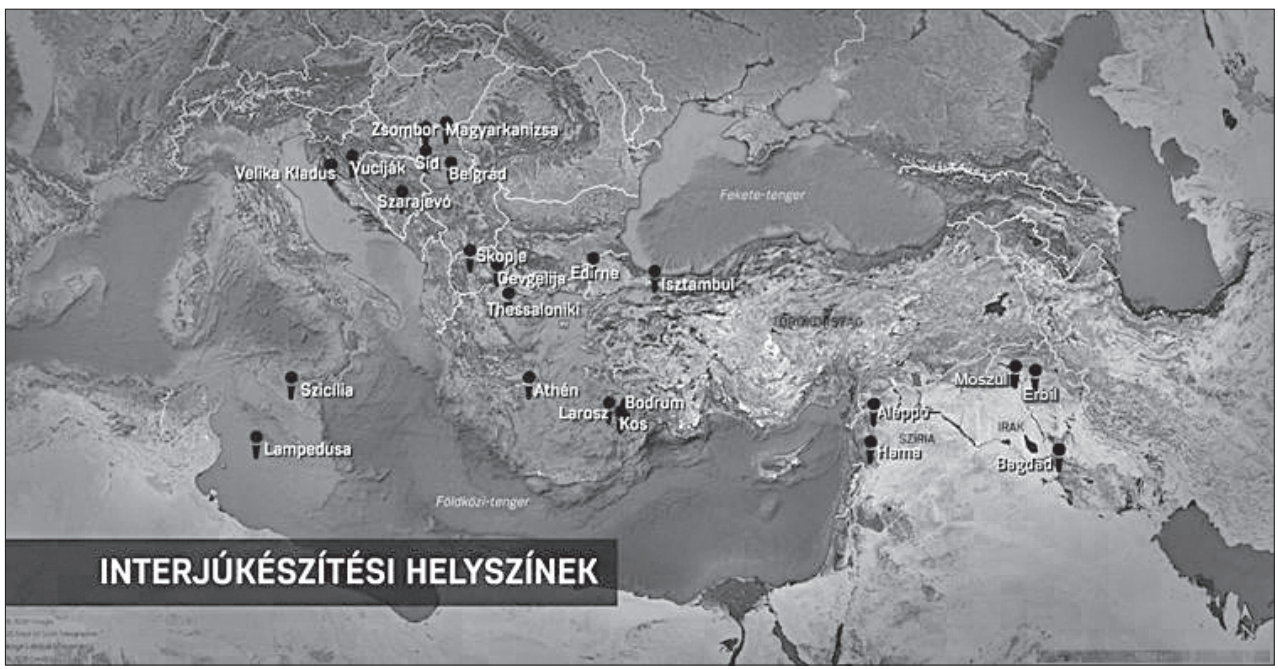

1. térkép Készitette a szerzö. Grafika: ATV

Az 1. térképen az elmúlt hat évben bejárt helyszíneket mutatom be, azokat, amelyek szoros kapcsolatban vannak a menekültválsággal. Ezekben a városokban és országokban készültek az interjúk, amelyek összegzését a következőkben ismertetem.

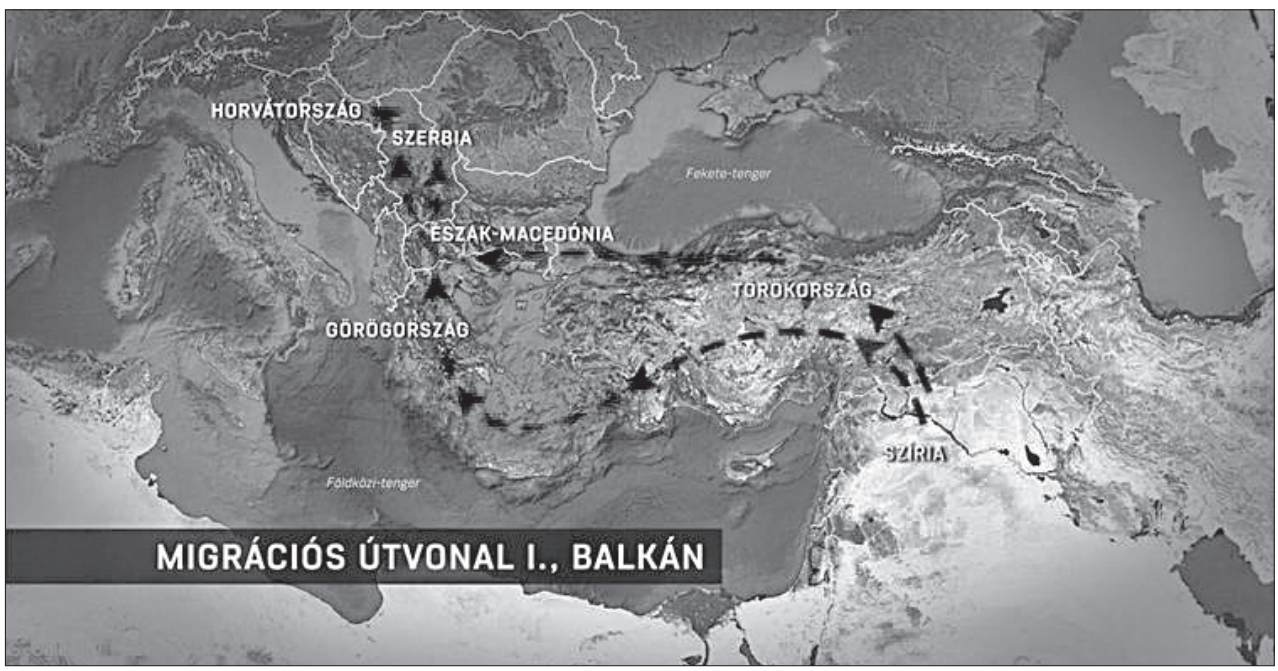

2. térkép Készitette a szerzö. Grafika: ATV 
Az elmúlt években kisebb-nagyobb változásokkal két, teljesen tiszta migrációs és/vagy csempészútvonal alakult ki. Amelyik jobban érinti Magyarországot, az a Balkánon keresztül vezet (I. migrációs útvonal, lásd 2. térkép), és 2020 elején szinte biztosan elmondható volt: ebből az irányból érkeztek a legtöbben. Itt kettévált az út: többségében az Égei-tengeren közelítették meg Görögországot, kisebb részük pedig az Évrosz-folyón (szárazföldön) keresztül. Görögország a balkáni migrációs vagy csempészútvonalak legfontosabb kiindulópontja, elöször ugyanis mindenki Görögországba érkezik, s csak ezt követően indul tovább.

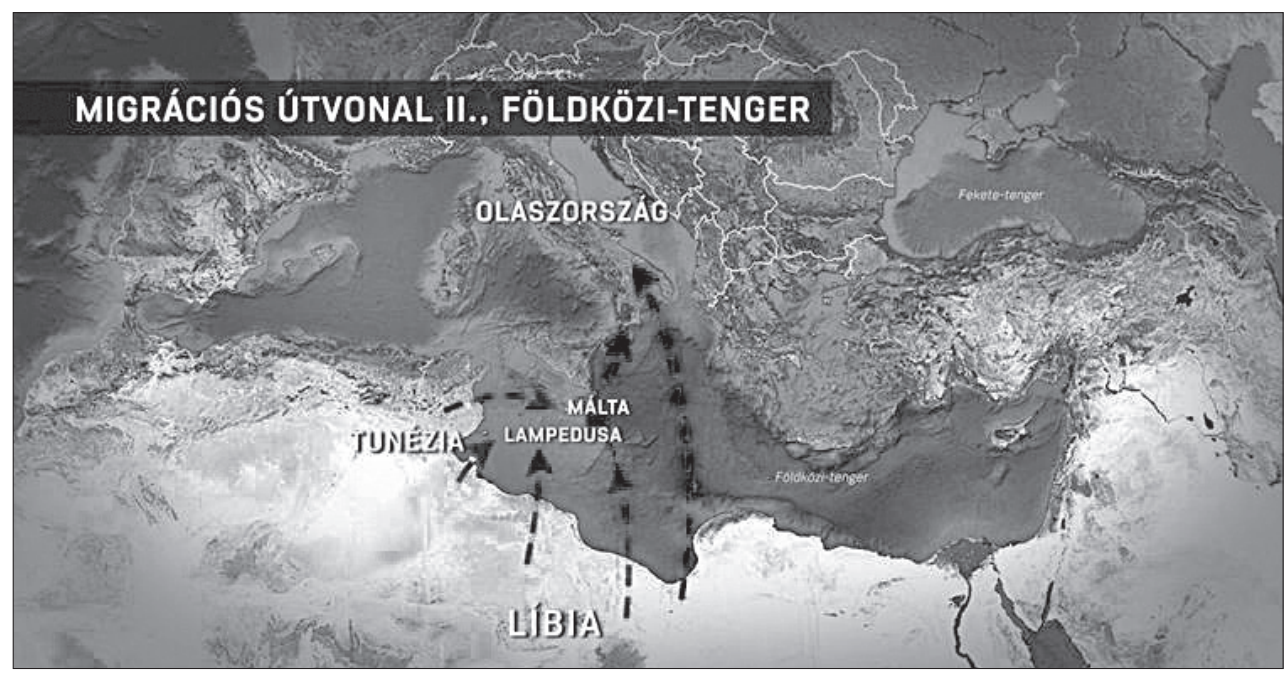

3. térkép Készitette a szerzö. Grafika: ATV

A II. migrációs útvonal (lásd 3. térkép) Észak-Afrikából kiindulva az olasz szigeteket és Máltát veszi célba. Ez számunkra kevésbé érdekes, de itt szinte heti rendszerességgel jelentek meg lélekvesztő bárkák és hajók tele menekültekkel. Még 2020 elején is volt olyan, hogy átlagosan napi 100-200 ember érte el az Európai Unió valamely szigetének partjait.

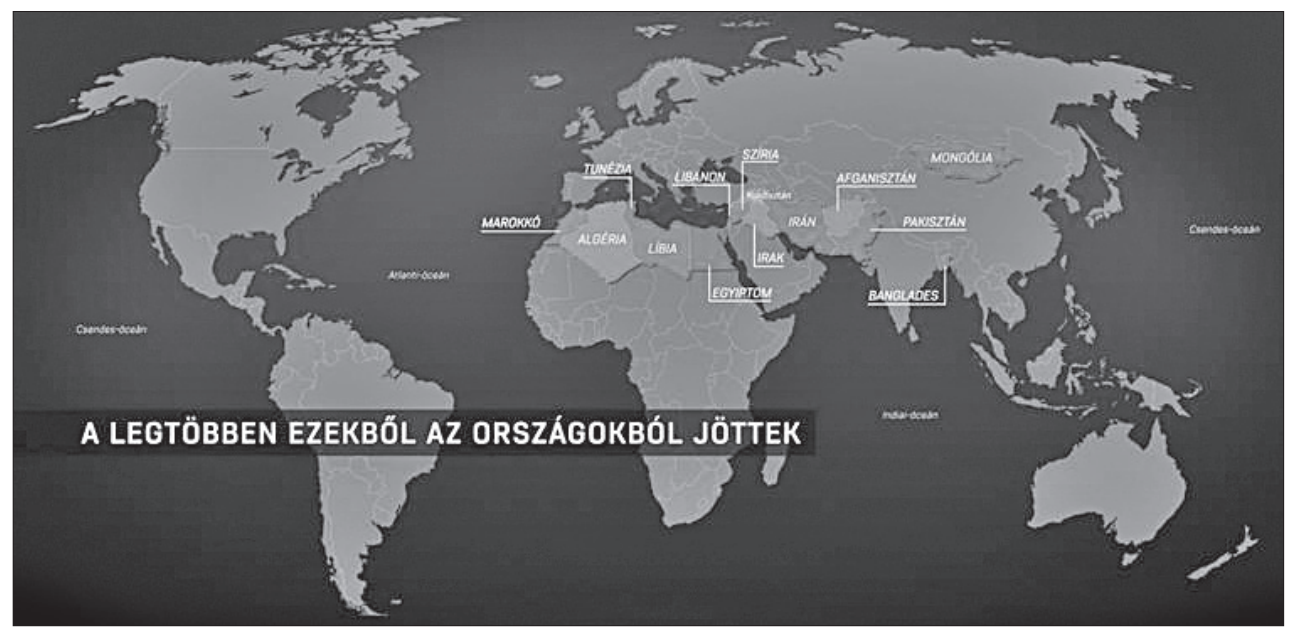

4. térkép Készitette a szerzö. Grafika: ATV 
A válaszadók 99\%-a a 4. térképen feltüntetett országokból érkezett. Az érkezők nemzetiségi aránya leginkább a politikai és háborús helyzettől függött. Az ISIS felszámolását követően sokkal többen jöttek Ázsiából, mint a Közel-Keletről. A Frontex adatai szerint az elmúlt hat évben így is 94 különböző országból érkeztek menekültek, bevándorlók, migránsok Európába.

\section{Tudta-e, hogy az európai határok le vannak zárva, és a belépés mindenképpen illegális?}

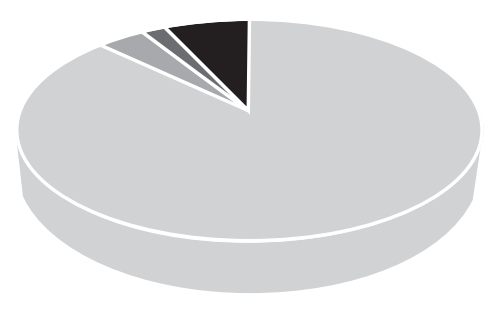

Összesített adatok:

Nem $-87 \%$

Nem, és még most sem hiszi el - 4\%

Igen, de tudta, hogy ennek ellenére

be lehet menni - $2 \%$

Igen, de életveszélyben volt - 7\%

\begin{tabular}{|l|l|}
\hline A Közel-Keletről érkezők válaszai: \\
\hline Nem & $77 \%$ \\
\hline Nem, és még most sem hiszi el & $1 \%$ \\
\hline Igen, de tudta, hogy ennek ellenére be lehet menni & $11 \%$ \\
\hline Igen, de életveszélyben volt & $11 \%$ \\
\hline
\end{tabular}

\begin{tabular}{|l|l|}
\hline Ázsiából érkezők válaszai: & $90 \%$ \\
\hline Nem & $1 \%$ \\
\hline Nem, és még most sem hiszi el & $6 \%$ \\
\hline Igen, de tudta, hogy ennek ellenére be lehet menni & $3 \%$ \\
\hline Igen, de életveszélyben volt &
\end{tabular}

\begin{tabular}{|l|l|}
\hline Afrikából érkezők válaszai: \\
\hline Nem & $89 \%$ \\
\hline Nem, és még most sem hiszi el & $2 \%$ \\
\hline Igen, de tudta, hogy ennek ellenére be lehet menni & $1 \%$ \\
\hline Igen, de életveszélyben volt & $8 \%$ \\
\hline
\end{tabular}

„,Semmit nem tudtunk. Azt mondták a barátaim, akik már Németországban vannak, hogy be lehet jönni. De nem is volt más választásom, teljesen lerombolták a házam, nem maradt semmim, ezért vagyok itt. Most én is Münchenbe szeretnék menni. Mindenem odaveszett a háborúban. Nincs vesztenivalóm, munkát szeretnék találni Európában és normális életet élni. Ehhez nekünk is jogunk van. Tudom, hogy Európában van esélyem új életet kezdeni, ezért is indultam el." (Mohamed Abdullah Szíriából) 
A válaszokból egyértelmúen kiderült: a nagy többség egyáltalán nem hallott arról, hogy az európai uniós országok megpróbálják megakadályozni a bejutást és határzárat alkalmaznak.

Az külön érdekesség, hogy az Ázsiából és Afrikából érkezők még kevesebb információval rendelkeztek a határhelyzetről. Akik viszont a Közel-Keletröl jöttek, sokkal jobban informáltak voltak. Ez annak köszönhetö, hogy a másik két régióból sokkal több szegény érkezett, akik kevésbé jutottak információhoz és internetkapcsolathoz.

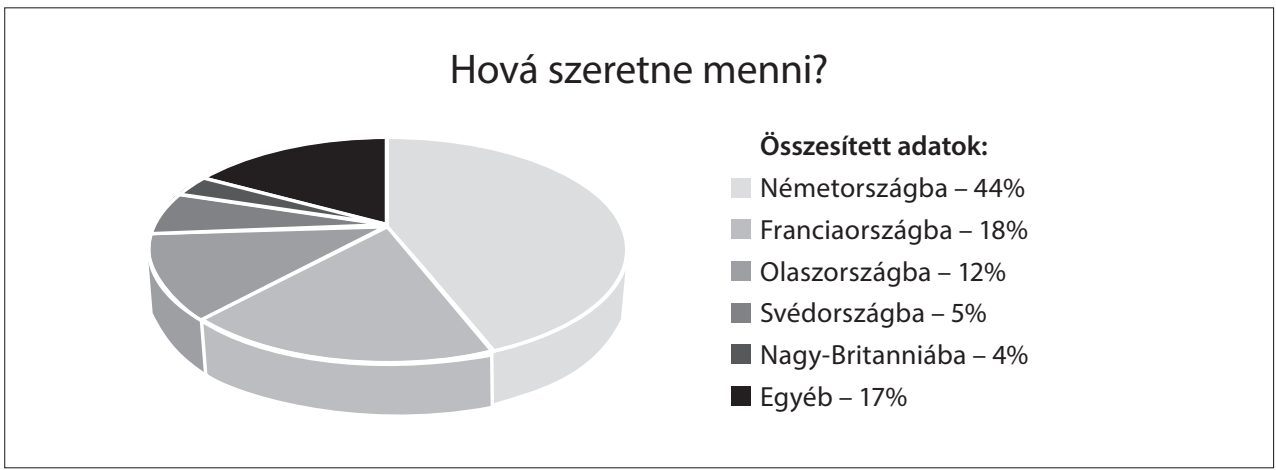

\begin{tabular}{|l|l|}
\hline \multicolumn{2}{|l|}{$\begin{array}{l}\text { A Közel-Keletröl érkezök } \\
\text { válaszai: }\end{array}$} \\
\hline Németországba & $44 \%$ \\
\hline Franciaországba & $12 \%$ \\
\hline Olaszországba & $10 \%$ \\
\hline Svédországba & $5 \%$ \\
\hline Nagy-Britanniába & $6 \%$ \\
\hline Egyéb & $13 \%$ \\
\hline
\end{tabular}

\begin{tabular}{|l|l|}
\hline \multicolumn{2}{|l|}{ Ázsiából érkezők válaszai: } \\
\hline Németországba & $66 \%$ \\
\hline Franciaországba & $10 \%$ \\
\hline Olaszországba & $12 \%$ \\
\hline Svédországba & $3 \%$ \\
\hline Nagy-Britanniába & $5 \%$ \\
\hline Egyéb & $4 \%$ \\
\hline
\end{tabular}

\begin{tabular}{|l|l|}
\hline \multicolumn{2}{|l|}{ Afrikából érkezők válaszai: } \\
\hline Németországba & $33 \%$ \\
\hline Franciaországba & $47 \%$ \\
\hline Olaszországba & $9 \%$ \\
\hline Svédországba & $2 \%$ \\
\hline Nagy-Britanniába & $4 \%$ \\
\hline Egyéb & $5 \%$ \\
\hline
\end{tabular}

„Éheztünk, nincs munka a környéken, a férjemet pedig megölték. Négy gyerekkel indultam el és Franciaországba tartok. Ez itt a görög menekülttábor, de szörnyüek a körülmények. Ahogy csak tudunk, indulunk tovább. Néha úgy bánnak velünk, mint az állatokkal. Az elsö héten még sátrat sem adtak. A gyerekekkel a földön aludtunk itt, a kerítés mellett. Ez nem élet igy. Naponta egyszer adnak enni. Alig várjuk már, hogy továbbmenjünk. Franciaországban van rokonom, hozzájuk igyekszünk. De a neheze még hátravan.” (Maria Shimal Csádból)

Az végig egyértelmü volt, hogy a menekültek legszívesebben Németországba, Franciaországba vagy Olaszországba utaznának. Ennek az egyik legfőbb oka az, hogy Németországból kapják a legtöbb örömteli hírt: információik szerint nagyon emberségesen bánnak velük, igen magas a menedékkérelmek pozitív elbírálása, emellett pedig viszonylag sok, 500-700 euró havi juttatást is kapnak a menekültstátusz elbírálásáig, illetve még utána is. 


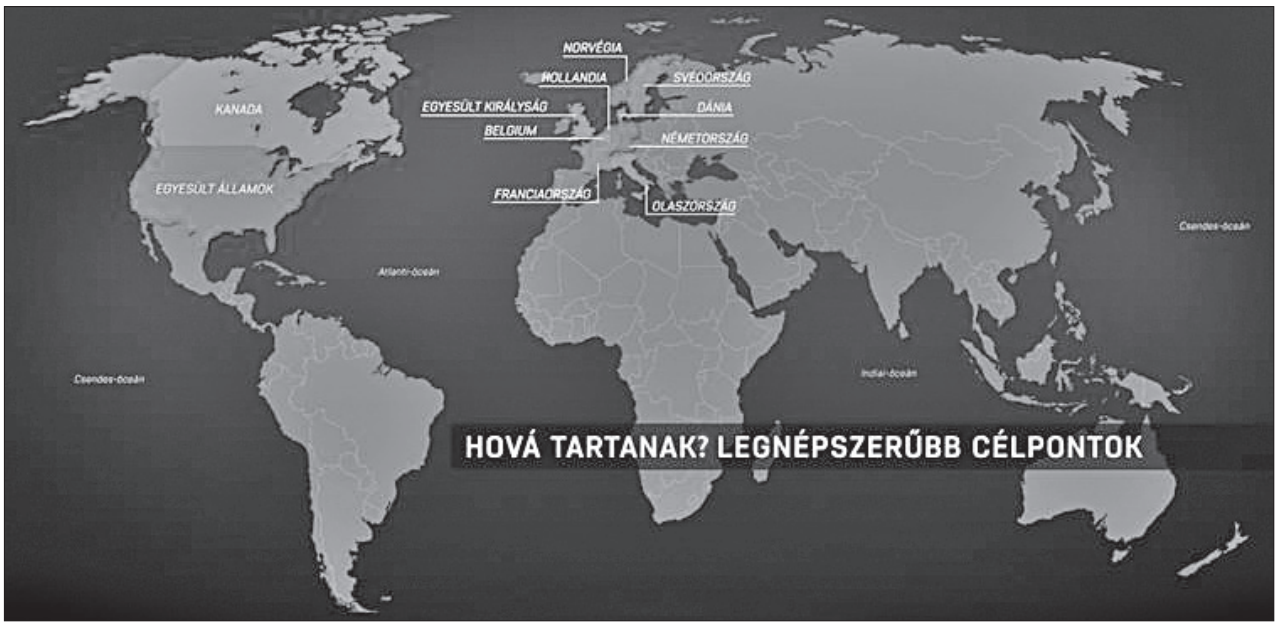

5. térkép Készitette a szerző. Grafika: ATV

Az 5. térképen is jól látható, hogy mindenképpen Nyugat-Európa leggazdagabb országai az elsődleges célpontok. (Az Amerikai Egyesült Államokat és Kanadát a Közép- és Dél-Amerikából induló bevándorlóhullám miatt tettem fel a térképre.) Ennek az oka az, hogy ezekben az európai országokban a legfejlettebb a menekültkezelési eljárás és ezeken a helyeken kapják a legtöbb támogatást vagy segélyt.

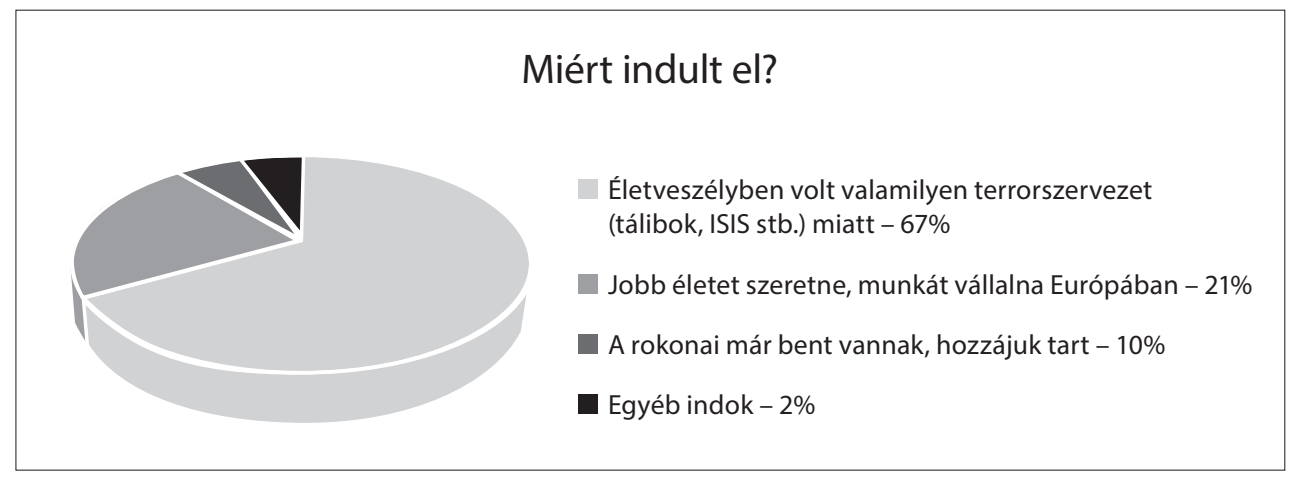

\begin{tabular}{|l|l|}
\hline Ázsiából érkezők válaszai: & \\
\hline Életveszélyben volt valamilyen terrorszervezet (tálibok, ISIS stb.) miatt & $55 \%$ \\
\hline Jobb életet szeretne, munkát vállalna Európában & $39 \%$ \\
\hline A rokonai már bent vannak, hozzájuk tart & $6 \%$ \\
\hline Egyéb indok & $5 \%$ \\
\hline
\end{tabular}

„Az ISIS minden családtagomat megölte. Egyedül maradtam. Nincs vesztenivalóm, ezért jöttem. Ujj életet szeretnék kezdeni Európában. Németországba vagy Olaszországba tartok. Ez a görög menekülttábor túlzsúfolt és mindenhonnan jönnek emberek. Nem csak háborús helyszínröl. Rengetegen vannak Pakisztánból, Iránból, Afganisztánból és Bangladesböl is. Mi is látjuk, hogy ez probléma, sokszor össze is kevernek minket.” (Musztafa Ibrahim, Irakból) 
A felmérés egyik legfontosabb kérdése az volt: „Miért indult el?” Legtöbbször a következő válasz érkezett: „Mert veszélyben volt az életem.” De ez sok esetben inkább betanult szöveg, amit a menekültek a különböző menekültügyi eljárások során és a hatóságok előtt adnak elö. Ezt a választ adják a legtöbbször a sajtónak is. Tapasztalataim szerint az egyik legfontosabb cél, hogy szánalmat és együttérzést keltsenek a hallgatóban. A migrációs hullám elején ez a válasz még valós tartalmat tükrözött. Az utóbbi két-három évben viszont inkább a jobb élet reményében érkezők száma nőtt meg. Talán ezen a ponton válik el, hogy ki a valódi menekült és ki az illegális bevándorló. A migráns kifejezés ez utóbbi esetben kap politikai felhangú, pejoratív értelmet.

\section{Érte valamilyen atrocitás vagy erőszak az utazása során?}

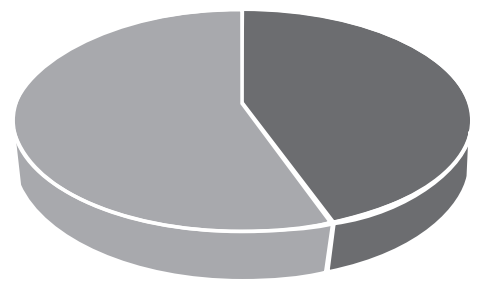

Igen $-45 \%$

Nem $-55 \%$

\begin{tabular}{|l|l|}
\hline \multicolumn{2}{|l|}{$\begin{array}{l}\text { Ha érte valamilyen atrocitás (föleg a hatóságok részéröl), } \\
\text { az melyik országban történt? }\end{array}$} \\
\hline Bulgária & $33 \%$ \\
\hline Horvátország & $19 \%$ \\
\hline Irán & $11 \%$ \\
\hline Észak-Macedónia & $11 \%$ \\
\hline Törökország & $9 \%$ \\
\hline Magyarország & $8 \%$ \\
\hline Románia & $5 \%$ \\
\hline
\end{tabular}

„Többször megvertek a rendörök, rám engedték a kutyákat. Mindkét karomat és a lábamat is megharapták. Úgy bántak velünk, mintha állatok lennénk. Ez Bulgáriában történt. Hidd el, életveszélyben voltunk a tálibok miatt! Ha nem tartod be a törvényeiket, akkor megfenyegetnek. Mindig életveszélyben. Egy rettegés Kabulban az élet. Én tolmács voltam, a szövetséges eröket segítettem, mert négy nyelven beszélek. De látták a tálibok, hogy együtt vagyok az amerikaiakkal és az angolokkal, és ez már elég volt nekik, hogy célponttá váljak. Így nem lehet élni. Az életemet mentettem azzal, hogy eljöttem.” (Mahmud Malek Afganisztánból)

\section{A rendőrkutya-dilemma}

A menekültek közt több olyan is volt, akit több országban is megvertek, vagy elvették a pénzét és/vagy a telefonját. Az atrocitást firtató kérdés ezért igen szenzitív téma. Elég nehéz objektívan leírni és elemezni a hallottakat. Hiszen rengeteg menekültet vertek meg vagy raboltak ki az 
utazásuk során többnyire a hivatásos állományba tartozó rendörök. Ezt az interjúk alkalmával igen sokan megerősítették. Rengetegen mutatták a sebeiket, amelyeket különböző rendőrkutyák okoztak. A legtöbbször, miután a telefonjukat és a pénzüket is elvették, visszalökdösték őket a legutolsó határon. Rengetegen panaszkodtak a bolgár rendőrség tagjaira, de sokan a magyar hatóságok hasonló eseteiről is beszámoltak. Ezt a mentalitást igen nehéz komplex és professzionális határvédelemnek nevezni, sokkal inkább agressziónak és lopásnak hangzik. Fontos megjegyezni azonban, hogy nem minden panaszkodó állítja a valóságot.

Ha az egyik oldalról nézzük: a kutyás határvédelem hatékony. Már csak azért is, mert még senki sem talált megfelelő, a migrációs hullámot igazán hatékonyan megállítani képes módszert. Azonban több tucat olyan sérült szemtanú beszámolóját hallgattam végig és rögzítettem kamerával, akiket rendőrkutyák haraptak vagy sebesítettek meg. Azaz hosszú perceken át marcangolták, harapták őket az erre kiképzett állatok. Nekünk, civileknek rettenetes lenne akár csak végignéznünk, ahogy fegyvertelen emberekre ugató, harapós kutyák támadnak.

Összegezve, a biztonság szempontjából fontos a szigorú határvédelem, ám napjaink társadalmában már elfogadhatatlan, emberiességellenes, hogy a rendészeti agresszió a szemünk előtt zajlik.

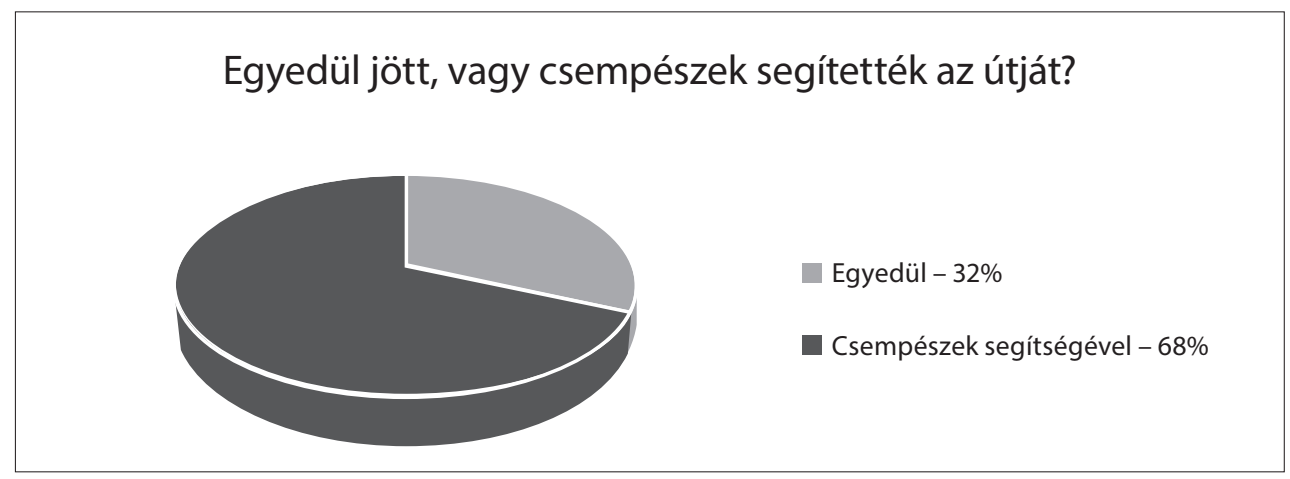

\begin{tabular}{|l|l|}
\hline \multicolumn{2}{|l|}{ Afrikából érkezők válaszai: } \\
\hline Egyedül & $45 \%$ \\
\hline Csempészek segítségével & $55 \%$ \\
\hline
\end{tabular}

\section{Mennyi pénzt költött embercsempészekre?}

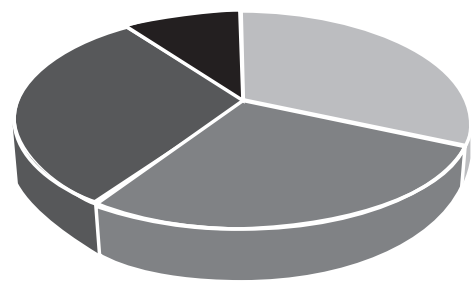

Nem költött csempészekre - 32\%

5000 euró alatt - $27 \%$

5-10 ezer uró között - 31\%

10 ezer euró felett - $10 \%$ 


\begin{tabular}{|l|l|}
\hline \multicolumn{2}{|l|}{ Afrikából érkezők válaszai: } \\
\hline Nem költött csempészekre & $38 \%$ \\
\hline 5000 euró alatt & $57 \%$ \\
\hline $5-10$ ezer euró között & $3 \%$ \\
\hline 10 ezer euró felett & $2 \%$ \\
\hline
\end{tabular}

„Alig van munka Pakisztánban. Napi 10 eurót kerestem. Ebböl nem lehet megélni. Van néhány barátom, akiket már bevittek az embercsempészek. Így jutottam el Boszniáig. Most az alkalmas idôt várom, hogy továbbmehessek.” (Mohammed Kamal Khan Pakisztánból)

A felmérésnek ez a pontja hallatlanul megdöbbentő képet mutat. Az rajzolódik ki belőle, hogy a nagy többség embercsempészek segítségével jön, és 70\%-uk jelentős összegeket költ a célállomásra való eljutásig. A menekültek többször megerősítették a beszélgetések kapcsán: havi szinten több tízmillió eurós üzletről van szó, amit a csempészek megkereshetnek ezzel az illegális tevékenységgel.

Az egyik leglényegesebb összetevő, amiért még most is müködik a balkáni útvonal, hogy rengeteg pénz van benne. Többen beszámoltak arról, hogy az albán és afgán maffia teljesen átállt a drogról az emberkereskedelemre. Jóval magasabb a profit, és a feladat szinte ugyanaz: illegálisan kell átszállítani [az árut] a határon. Kicsit nehezebb ugyan a menekülttel, mert lélegzik, mert levegő, víz és néha étel is kell neki, de jóval többet fizet, és ami szintén fontos, hogy elöre. Ezért is müködnek könnyen az embercsempész-útvonalak.

Ez az eredmény nem igazán megdöbbentő. Egyszerű a képlet: a csempészeknek nem érdekük átverni az ügyfeleket. Az utazó, ha elégedett, máris hazatelefonál, mondjuk Kabulba vagy Iszlámábádba, hogy például Alinál érdemes befizetni egy müncheni járatra, mert tudja teljesíteni. Ez pedig müködik. A csempészek 100\%-os bejutást ígérnek 5-10 ezer euróért cserébe.

\section{Átverték-e a csempészek?}

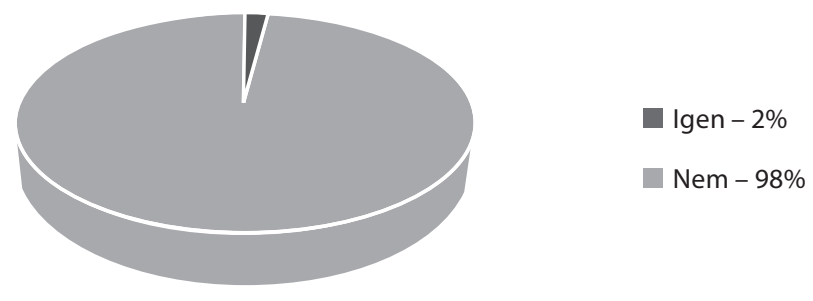


Amikor szembesült vele, hogy nehezebb bejutni (például a határzárak miatt), gondolt rá, hogy visszafordul?

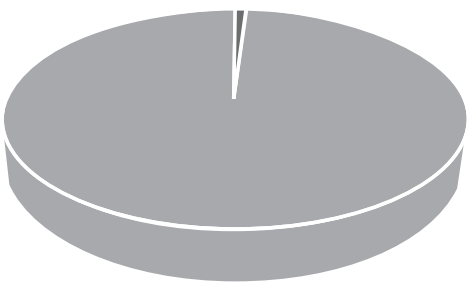

Igen $-1 \%$

Nem - 99\%

Ha változik a helyzet az országában, akkor visszamegy?

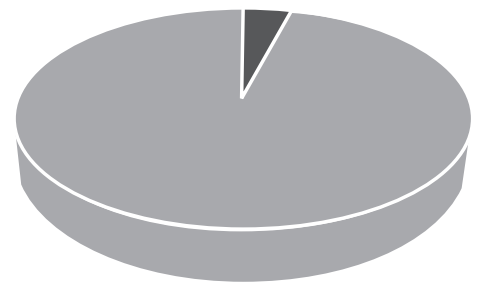

Igen $-4 \%$

Nem $-96 \%$

Mennyi ideig tartott az utazása Szerbiáig?

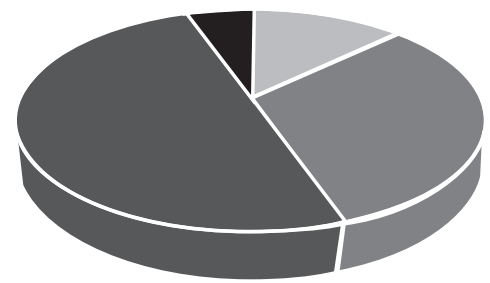

3 hétnél kevesebb ideig - 12\%

3 hét és 3 hónap között - 28\%

3 hónapnál tovább - 55\%

1 évnél is tovább - 5\%

Hallott-e olyan menekültről, akit visszatoloncoltak?

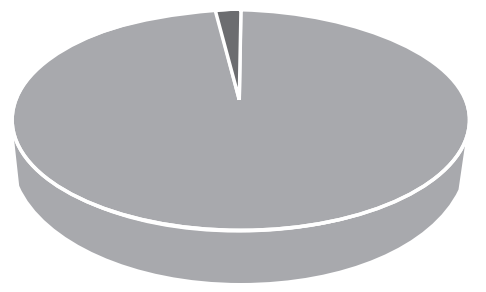

Igen - 2\%

Nem - 98\% 


\section{ÖSSZEGZÉS}

Bár kutatásom nem reprezentatív jellegü, ennek ellenére az adatokból egyértelműen kimutatható: az embercsempészek kommunikációja sokkal sikeresebb, mint az európai országoké. Hiszen a menekültek nagy többsége (90\%) úgy tudja: az Európai Unióba könnyen be lehet jutni illegálisan. Arról egyáltalán nem hallottak, hogy néhány ország határzárat létesített. Ezzel ellentétben arról számoltak be - és az adatok is erről árulkodnak -, hogy a csempészek egyértelmüen be tudják tartani az ígéreteiket, és átviszik, illetve bejuttatják őket bizonyos európai uniós országokba. A felmérésből az is kiderül, hogy a legtöbben azért indulnak el, mert jobb életet kívánnak maguknak. Jobb fizetést és magasabb életszínvonalat szeretnének ahhoz képest, mint ahol éltek.

Azt már korábban lehetett tudni, hogy a közel-keleti háború befejezése után jelentősen megváltoznak az indulási állomások. Míg korábban a menekültek jellemzően az ISIS miatti háborúra hivatkoztak, addig mostanra ez már gazdasági okokra változott. Jelenleg (föleg Afganisztánból, Iránból és Pakisztánból) azok jönnek, akik jobb életben reménykednek. Ök a tipikus gazdasági bevándorlók. A vizsgálatból az is kirajzolódik, hogy a nagy többséget érte valamilyen rendőri atrocitás, azaz megverték vagy kirabolták őket, elvették a pénzüket vagy éppen a telefonjukat.

Az is egyértelműen kiolvasható a kutatásból, hogy a menekültek rengeteg pénzt költenek az illegális határátlépésre. Természetesen átlagot nagyon nehéz számolni, hiszen mindenki utazása egyedi, de abban megerősítettek, hogy átlagosan 4-10 ezer euró között költenek arra, hogy 3-6 országot átszelve bejussanak valamelyik uniós államba. Ha a szerb migrációs hivatal adatait vesszük alapul, azt lehet mondani, hogy Szerbián 2019-től napjainkig körülbelül 30 ezer ember ment át. Az is elgondolkodtató, hogy a megkérdezettek nem is hallottak olyanról, akit visszatoloncoltak a hazájába. A kérdésekre adott válaszok alapján abban teljes az egyetértés, hogy senki sem fordul vissza. Ha már elindult, be is fejezi az utat. Azt mondták, nem az a kérdés, hogy bejutnak-e, csak az, hányadik próbálkozásra.

Tanulságként elmondhatjuk, hogy 2019-re az illegális embercsempész-útvonalak kifejezetten jól müködtek. Ha valaki úgy döntött Iszlámábádban vagy Kabulban, hogy el akar menni Németországig vagy Franciaországig, akkor 5000-8000 euróval a zsebében szinte biztosan meg tudta tenni.

A megoldás az lehetne, ha az európai uniós országok a legfrekventáltabb kiinduló országokban megfelelő mértékű és hatásos reklámokkal kezdenék el hirdetni: tilos az átjárás és a bejárás! Például televízió-, újság- és rádióreklámok szólhatnának arról, hogy az uniós határok le vannak zárva. Talán ez lehetne az első lépés a migrációs válság kezelésében.

\section{FELHASZNÁLT IRODALOM}

1989. évi 15. törvényerejü rendelet a menekültek helyzetére vonatkozó 1951. évi július hó 28. napján elfogadott egyezmény, valamint a menekültek helyzetére vonatkozóan az 1967. évi január hó 31. napján létrejött jegyzőkönyv kihirdetéséről. https://net.jogtar.hu/jogszabaly?docid=98900015.tvr

Andorka Rudolf: Bevezetés a szociológiába. Osiris, Budapest, 2006.

Besenyő János - Miletics Péter József (szerk.): Szemelvények a XXI. századi migráció témaköréböl.

Honvéd Vezérkar Tudományos Kutatóhely (HVK TKH), Budapest, 2017. http://real.mtak.hu/83709/1/ szemelvenyek.pdf

Csuka Gyöngyi - Török Ádám (szerk.): Az Európába irányuló és 2015-től felgyorsult migráció tényezöi, irányai és kilátásai. MTA Migrációs Munkacsoport, Budapest, 2015. 
Dr. Dezső Tamás: Demográfia és migráció: a muszlim világ népességrobbanásának okai és következményei. Migrációkutató Intézet. https:/www.migraciokutato.hu/2018/12/11/a-muszlim-vilagnepessegrobbanasanak-okai-es-kovetkezmenyei/.

Háber Péter: Az „Iszlám Állam” nevü terrorista szervezet és az általa gerjesztett biztonsági kockázatok. Szakmai Szemle, 2016/3., 55-82.

Hermann, Rainer: Az Iszlám Állam. A világi állam kudarca az arab világban. Akadémiai Kiadó, Budapest, 2015.

Huszonkét éve nem látott számú menedékkérő érkezett 2014-ben a világ fejlett ipari országaiba. https:// www.unhcr.org/hu/393-huhirek2015huszonket-eve-nem-latott-szamu-menedekkero-erkezett-2014ben-a-vilag-fejlett-ipari-orszagaiba-html.html

Kasznár Attila: Az ujgur terrorizmus nemzetközi biztonsági kockázatai. Arc és Álarc, I. évf. 2017/2-3., 181-189.

Magyar Levente: A migráció a legnagyobb biztonsági kihivás Európában. https://magyarnemzet.hu/ kulfold/magyar-levente-a-migracio-a-legnagyobb-biztonsagi-kihivas-europaban-7563518/

Dr. Probáld Ferenc - Dr. Szegedi Nándor: Afrika és a Közel-Kelet gazdaságföldrajza. Tankönyvkiadó Vállalat, Budapest, 1986.

Resperger István (szerk.): Nemzetbiztonsági alapismeretek. Dialóg Campus Kiadó, Budapest, 2018.

Ritecz György: A migráció trendjei - és ami mögötte van. Regio, 24. évf. 2016/2., 109-139. http://regio. tk.mta.hu/index.php/regio/article/view/115; DOI: 10.17355/rkkpt.v24i2.115

Ritecz György - Sallai János: A migráció trendjei, okai és kezelésének lehetöségei 2.0. Central European Papers, IV. évf. 2016/2., 104-106.

Simon Péter: Az arab tavasz kiváltó okai, jelene és hatása a biztonságpolitika alakulására. Felderítő Szemle, XIII. évf. 2014/1., 17-25.

Szilágyi-Kiss Hajnalka: Az Iszlám Állam megerősödésének logisztikai háttere. Honvédségi Szemle, 149. évf. 2021/5.

Tálas Péter: Az európai migrációs válság értelmezési kereteiről. Nemzet és Biztonság, 2016/6., 86-115.

http://bamf.de/EN/DasBAMF/dasbamf.node.html

https://frontex.europa.eu/search-results/?q=In+2014+and+the+first + half + of $+2015+$ to + the + Schengen tarea

http://www.bmbah.hu/index.php?option=com_k2\&view=itemlist\&task=category\&id=11:bekescsaba \&Itemid $=885 \&$ lang $=$ hu 